\title{
Production of the Modified Liquid Glass in the Processing of Kaolinitic Clay
}

\author{
G. Sarsenbay, V. A. Kovzalenko, N. M.-K. Sadykov, A. O. Kaldybaeva \\ Institute of Metallurgy and Benefication, JSC, Science and Education Ministry of the Republic of Kazakhstan, Almaty, Kazakhstan \\ Email: mer-pa@mail.ru
}

How to cite this paper: Sarsenbay, G., Kovzalenko, V.A., Sadykov, N.M.-K. and Kaldybaeva, A.O. (2016) Production of the Modified Liquid Glass in the Processing of Kaolinitic Clay. World Journal of Engineering and Technology, 4, 151-157.

http://dx.doi.org/10.4236/wjet.2016.43D018

Received: September 8, 2016

Accepted: October 13, 2016

Published: October 20, 2016

\begin{abstract}
Production of modified liquid glass and quartz materials from kaolinite clay of Alekseev deposit of Kazakhstan was studied. The sodium liquid glass processed by kaolinite clay, with chemical composition $\left(\mathrm{g} / \mathrm{dm}^{3}\right): \mathrm{SiO}_{2}-350 ; \mathrm{Na}_{2} \mathrm{O}-155 ; \mathrm{Al}_{2} \mathrm{O}_{3}-2.1 ; \mathrm{Fe}_{2} \mathrm{O}_{3}$ 0.3 , silicate module- 2.33 and density $-1.49 \mathrm{~g} / \mathrm{cm}^{3}$ has been used. The sodium liquid glass complies with the Russian Interstate standard 13078-81 for sodium liquid glass. 10 samples of modified liquid glass were synthesized by introducing modifiers in an amount of $4 \%$ by weight of the solution into the liquid glass. Hard quartz material produced by using synthesized modified liquid glass was obtained. It has been established that the obtained modified liquid glass from kaolinite clay can improve the strength of the quartz material for 1.6 - 3.12 times higher than the initial liquid glass. Using liquid glass modifier to the inorganic sodium nitrate $\left(\mathrm{NaNO}_{3}\right)$ increases the strength 3.12 times.
\end{abstract}

\section{Keywords}

Modified Liquid Glass, Quartz Fraction, Modifier, Kaolinite Clay, Strength

\section{Introduction}

As the inorganic binder, liquid glass is perspective material in the production of ceramics, composites and coverings silicate [1]. Simultaneously, during the long-term storage, polymerization reactions may occur spontaneously in the liquid glass, which lead to the "aging" and reducing strength and heat resistance of products and limiting the periods of storage and operating. These problems can be solved by substituting the traditional liquid glass with the modified liquid glass. Materials obtained on the basis of the modified liquid glass have high strength, durability, heat resistance, water resistance and other performance characteristics [2]. 
In the previous studies modified liquid glasses were obtained mostly by traditional method of modification with sodium, potassium or lithium liquid glass and their mixtures with the silicate modulus in the range $2-5$. The process for obtaining the modified liquid glass carried out by physical and chemical methods of modification using organic and inorganic modifiers. Chemical modification has proven to be an effective way [3].

To reduce manufacturing costs for the production of the modified liquid glass, we offer a way to simultaneously produce sodium modified liquid glass from low-quality aluminum-containing raw material-kaolinite clay at their complex processing. Complex processing of kaolinite clays allows obtaining an enriched concentrate of kaolin and aluminum oxide for the production of alumina. Excess silica of kaolinite clays can be used as raw materials for the production of silicate products, including liquid and liquid-modified glass. The liquid glass obtained from excess quartz fraction can be used to modification processes, by leaching with sodium hydroxide under optimal conditions [4]-[6].

\section{Experiment}

Chemical composition of kaolinite clay was found to be $69.6 \% \mathrm{SiO}_{2} ; 19.3 \% \mathrm{Al}_{2} \mathrm{O}_{3} ; 0.97 \%$ $\mathrm{Fe}_{2} \mathrm{O}_{3} ; 0.15 \% \mathrm{Na}_{2} \mathrm{O} ; 0.01 \% \mathrm{~S}_{2} \mathrm{O}_{3} ; 0.6 \% \mathrm{~K}_{2} \mathrm{O} ; 6.3 \%$ LOI and silicic module- 0.28 for obtaining the solution of sodium liquid glass [7].

The excess quartz fraction of kaolinite clay was separated by elutriation. There have been received $46 \%$ quartz fraction and $54 \%$ of clay fraction after the process of washing. The clay fraction will be directed for obtaining of purified kaolin and aluminum oxide concentrate. The quartz fraction was used to produce a liquid glass by leaching with sodium hydroxide solution at the optimal conditions [8].

As a result there have been developed sodium liquid glass, complies with the Russian Interstate standard 13078-81 for sodium liquid glass, with chemical composition $\left(\mathrm{g} / \mathrm{dm}^{3}\right): \mathrm{SiO}_{2}-350 ; \mathrm{Na}_{2} \mathrm{O}-155 ; \mathrm{Al}_{2} \mathrm{O}_{3}-2,1 ; \mathrm{Fe}_{2} \mathrm{O}_{3}-0,3$, silicate module-2.33 and density$1.49 \mathrm{~g} / \mathrm{cm}^{3}$. The percentage of components (\%): $\mathrm{SiO}_{2}-27.74 ; \mathrm{Na}_{2} \mathrm{O}-12.3 ; \mathrm{Al}_{2} \mathrm{O}_{3}-0.15$; $\mathrm{Fe}_{2} \mathrm{O}_{3}-0.02$. Content of impurities oxides (\%): $\mathrm{Al}_{2} \mathrm{O}_{3}+\mathrm{Fe}_{2} \mathrm{O}_{3}-0.17$ (the content of impurities does not exceed $0.25 \%-0.4 \%$ ) [9].

The following modifiers are using to the processes of modification: starch $\left(\mathrm{C}_{6} \mathrm{H}_{10} \mathrm{O}_{5}\right)$ $\mathrm{n}$, sodium hexametaphosphate $\left(\mathrm{NaPO}_{3}\right)_{6}$, PEG-polyethylene glycol $\left.\left(\mathrm{C}_{2} \mathrm{H}_{4} \mathrm{O}\right) \mathrm{nH}_{2} \mathrm{O}\right)$, dextrin $\left(\mathrm{C}_{6} \mathrm{H}_{10} \mathrm{O}_{5}\right) \mathrm{n}, \mathrm{KBr}$ (potassium bromide), $\mathrm{KNO}_{3}$ (potassium nitrate), $\mathrm{NaBr}$ (Sodium bromide), $\mathrm{NaNO}_{3}$ (sodium nitrate), $\mathrm{Na}_{2} \mathrm{~B}_{4} \mathrm{O}_{7} \cdot 10 \mathrm{H}_{2} \mathrm{O}$ (borax) and sorbitol $\left(\mathrm{C}_{6} \mathrm{H}_{14} \mathrm{O}_{6}\right)$.

The obtained sodium silicate solution was used to produce modified liquid glass. In this case, modifiers in an amount of 6 grams (4\% by weight of liquid glass solution) were introduced into the original liquid glass of $100 \mathrm{ml}$. Contacting and mixing of modifiers with liquid glass carried out at $80^{\circ} \mathrm{C}$ for 30 minutes. The obtained modified liquid glass was placed under the room temperature for two days until complete homogenization. 
It is known, that the materials derived from modified liquid glasses possess improved performance characteristics in comparison with material of obtained from traditional liquid glass. Strength is one of the main characteristics of the materials, which was obtained by using liquid glass.

The strength of hard materials obtained by using modified liquid glass, initial liquid glass and quartz from kaolinite clay was tested.

To study the strength of the materials obtained on the basis of the modified liquid glass and initial liquid glass, taken a similar amount $(45 \mathrm{~g}$ ) of the sand (quartz) fraction separated from kaolinite clay, which is mixed with $1.5 \mathrm{ml}$ of the obtained various kinds of plasticizer (the initial and the modified liquid glass). Then, blanks in the form of tablets with diameter of $36 \pm 0.1 \mathrm{~mm}$ and a height of $20 \pm 0.1 \mathrm{~mm}$ was formed in a hydraulic press-Metallkraft WPP50M by pressing, which were dried in an oven at $105^{\circ} \mathrm{C}$ for 5 hours in the beginning.

After cooling within 24 hours, the obtained samples were carried out calcinations at $200^{\circ} \mathrm{C}$ for 3 hours; the samples were weighed before and after calcining.

\section{Result}

Sample of kaolinite clay from Alekseev deposits of Kazakhstan were used for experiments on the obtaining of modified liquid glass. The phase composition of the sample of kaolinite clay from Alekseev deposits was identified according to X-ray diffraction analysis: $67.5 \%$ quartz, $31.4 \%$ kaolinite- $\mathrm{Al}_{2}\left(\mathrm{Si}_{2} \mathrm{O}_{5}\right)(\mathrm{OH})_{4}$ and $1.1 \%$ muscovite$\mathrm{KAl}_{2}\left(\mathrm{AlSi}_{3}\right) \mathrm{O}_{10}\left(\mathrm{OH}_{1} \mathrm{~F}\right)_{2}$ (Figure 1).

Alekseev kaolinite clay deposit contains a significant amount of silicon oxide-quartz fraction, there was shown results of X-ray and chemical analysis. Quartz fraction consists of quartz phase (Figure 2), the clay fraction of the following composition: (\%), $\mathrm{Al}_{2} \mathrm{O}_{3}-31.2 ; \mathrm{SiO} 2-51.6 ; \mathrm{Fe}_{2} \mathrm{O}_{3}-0.53 ; \mathrm{Na}_{2} \mathrm{O}-0.095 ; \mathrm{K}_{2} \mathrm{O}-1.5$; LOI 6.3. Silicic module-0.61.

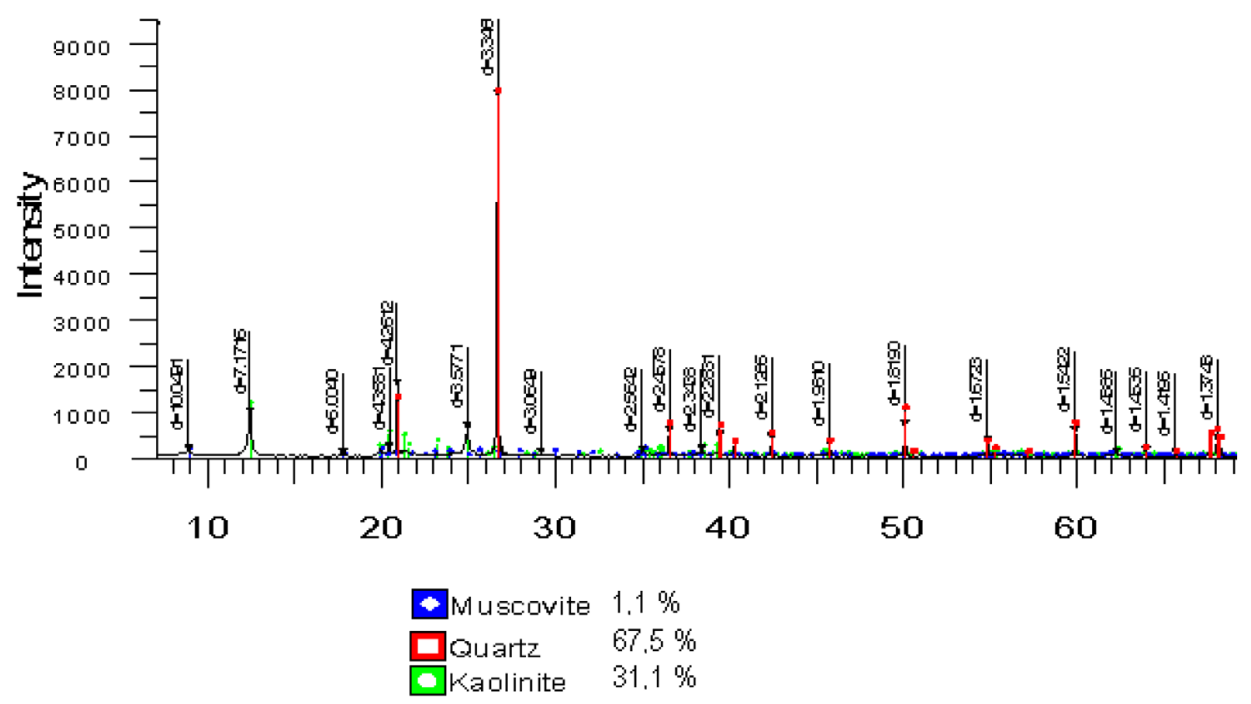

Figure 1. The X-rays diffraction pattern of kaolinite clay. 


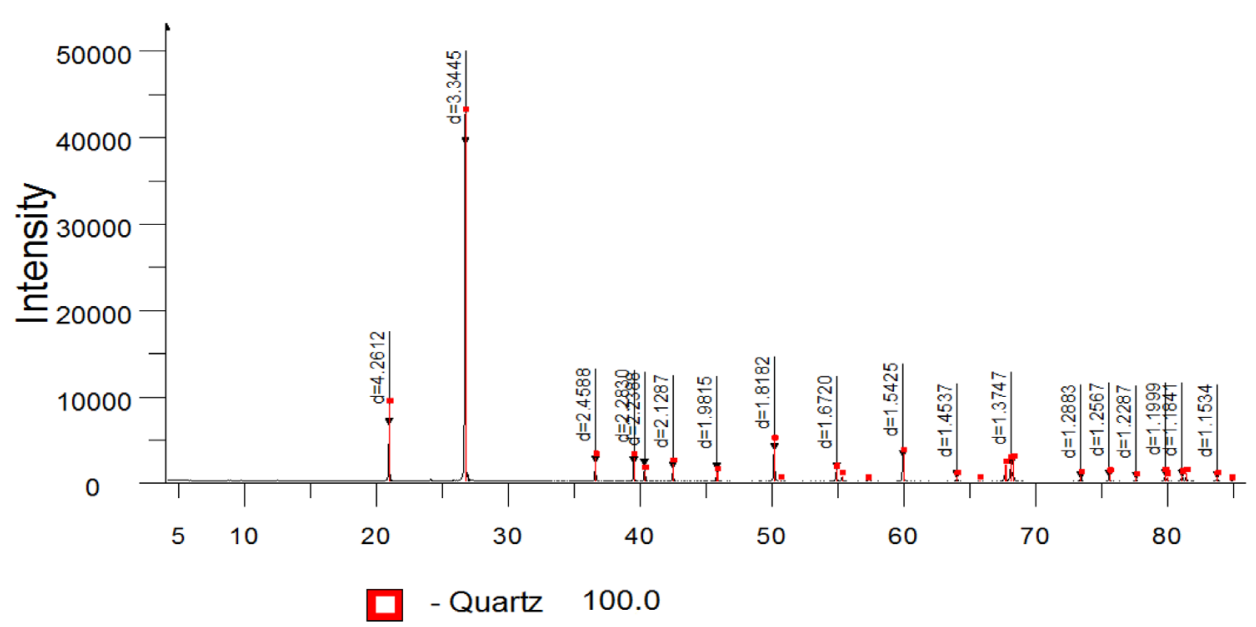

Figure 2. The X-rays diffraction pattern of the quartz fraction of kaolinite clay.

As a result, the sodium liquid glass processed by kaolinite clay, with chemical composition $\left(\mathrm{g} / \mathrm{dm}^{3}\right): \mathrm{SiO}_{2}-350 ; \mathrm{Na}_{2} \mathrm{O}-155 ; \mathrm{Al}_{2} \mathrm{O}_{3}-2.1 ; \mathrm{Fe}_{2} \mathrm{O}_{3}-0,3$, silicate module-2.33 and density- $1.49 \mathrm{~g} / \mathrm{cm}^{3}$ (complies with the Russian Interstate standard 13078-81 for sodium liquid glass) has been used for production of the modified liquid glass.

Composition of clay fraction reflected by X-ray analysis: $63.2 \%$ kaolinite, $21.6 \%$ quartz and $15.3 \%$ muscovite) (Figure 3 ).

The clay fraction-enriched kaolinite clay as a commodity product can head to the processing of industry and a process for producing aluminum oxide concentrate. The quartz fraction was used for obtain liquid glass by leaching with sodium hydroxide under optimal conditions, then obtained liquid glass subjected modification process to investigate the effect of modifiers.

As a result, we obtained 10 kinds of modified liquid glass.

Materials derived from various liquid glasses, characterized by different physicalchemical properties. One of the main characteristics of the liquid glass is the strength.

There have been carried out the process of identification the strength of the samples obtained modified liquid glass and original liquid glass. The number and kind of modifiers for the samples are shown in Table 1.

Studied the strength materials derived from the quartz fractions by using modified liquid glass (number of 2 - 11) and initial liquid glass (number 1) (Table 1), produced 11 molded specimens (diameter-3.6 cm, height $-2.0 \mathrm{~cm}$ ), which in the beginning were dried in an oven at $105^{\circ} \mathrm{C}$ for 5 hours. After cooling the obtained samples were carried out calcinations; the samples were weighed before and after calcinations. There was a slight decrease in the weight of the samples-about $0.25 \%$ (Figure 4).

Results for the test on the strength of samples obtained by using modified liquid glass and initial liquid glass are given in Figure 5.

The data in Figure 5 shows that the obtained modified liquid glass from kaolinite clay can improve the strength of the quartz material for 1.6 - 3.12 times higher than the initial liquid glass. 


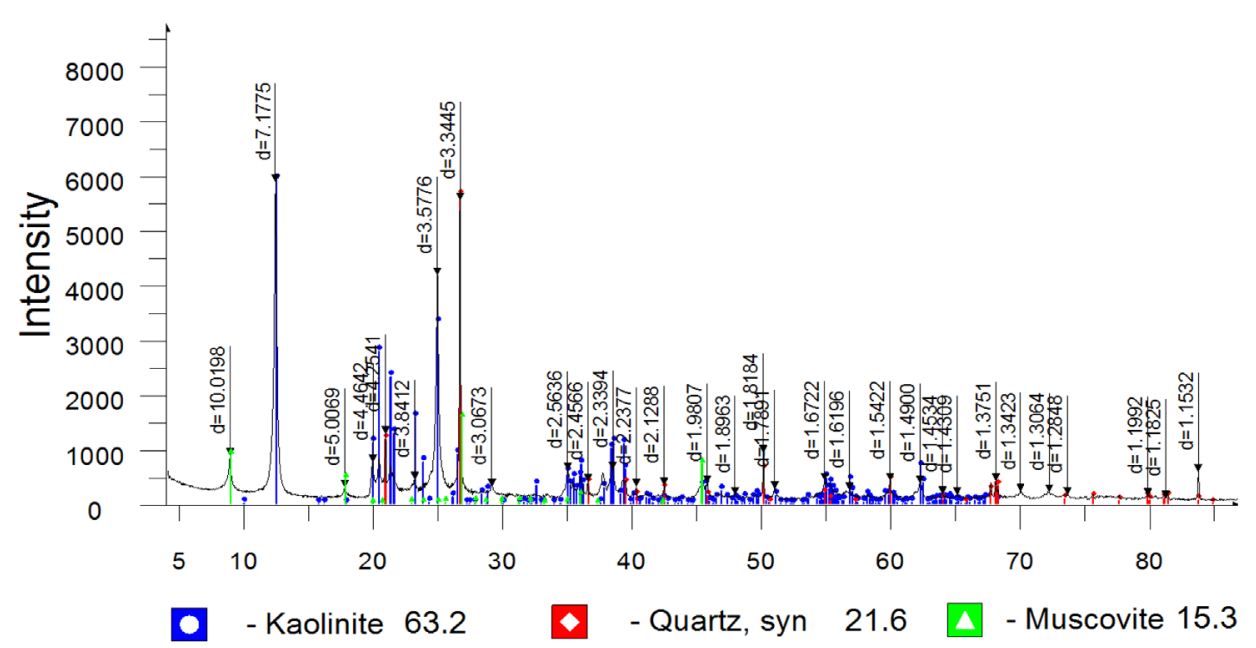

Figure 3. The X-ray analysis of clay fraction of kaolinite clay.

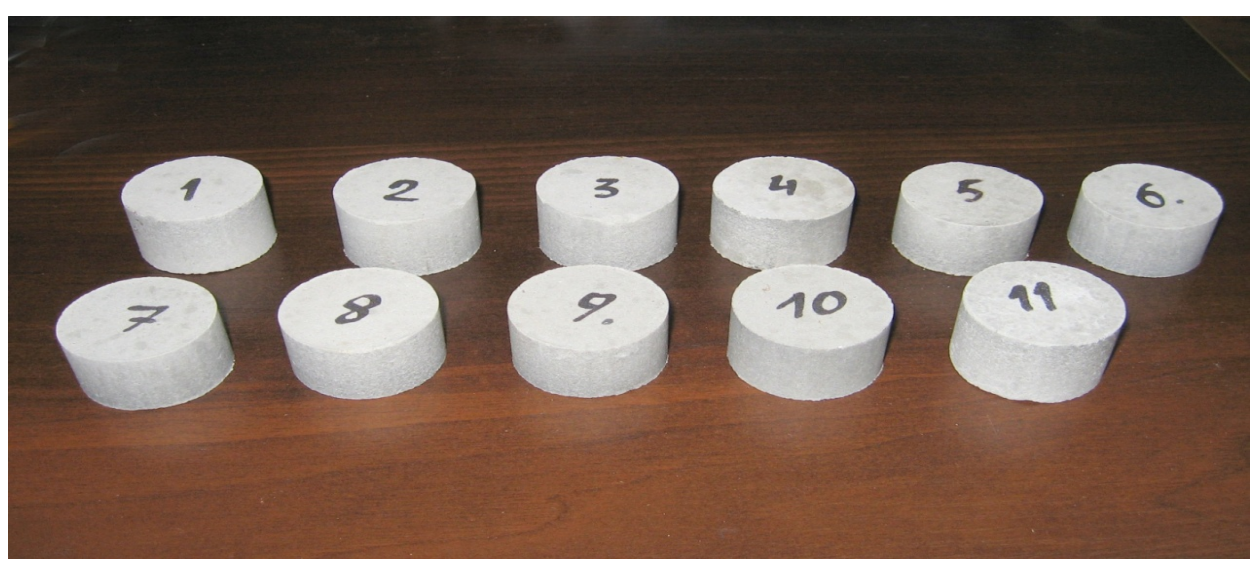

Figure 4. Samples for test of strength.

Table 1. The number and kind of modifiers for the samples.

\begin{tabular}{ccc}
\hline \multirow{2}{*}{ Number } & \multicolumn{2}{c}{ Kind of modifiers } \\
\cline { 2 - 3 } & Name & Formula \\
\hline 1 & - & - \\
2 & Starch & $\left(\mathrm{C}_{6} \mathrm{H}_{10} \mathrm{O}_{5}\right) \mathrm{n}$ \\
3 & Polyethylene glycol & $(\mathrm{KBr})$ \\
4 & Dextrin & $\left.\mathrm{C}_{2} \mathrm{H}_{4} \mathrm{O}\right)_{\mathrm{n}} \mathrm{H}_{2} \mathrm{O}$ \\
5 & Borax & $\left(\mathrm{C}_{6} \mathrm{H}_{10} \mathrm{O}_{5}\right) \mathrm{n}$ \\
6 & Potassium nitrate & $\mathrm{Na}_{2} \mathrm{~B}_{4} \mathrm{O}_{7} 10 \mathrm{H}_{2} \mathrm{O}$ \\
7 & Sodium bromide & $\mathrm{KNO}_{3}$ \\
8 & Sorbitol & $\mathrm{NaBr}$ \\
9 & Hexametaphosphate & $\mathrm{C}_{6} \mathrm{H}_{14} \mathrm{O}_{6}$ \\
10 & Sodium nitrate & $\left(\mathrm{NaPO}_{3}\right)_{6}$ \\
\hline 1 & & $\mathrm{NaNO}_{3}$ \\
\hline
\end{tabular}




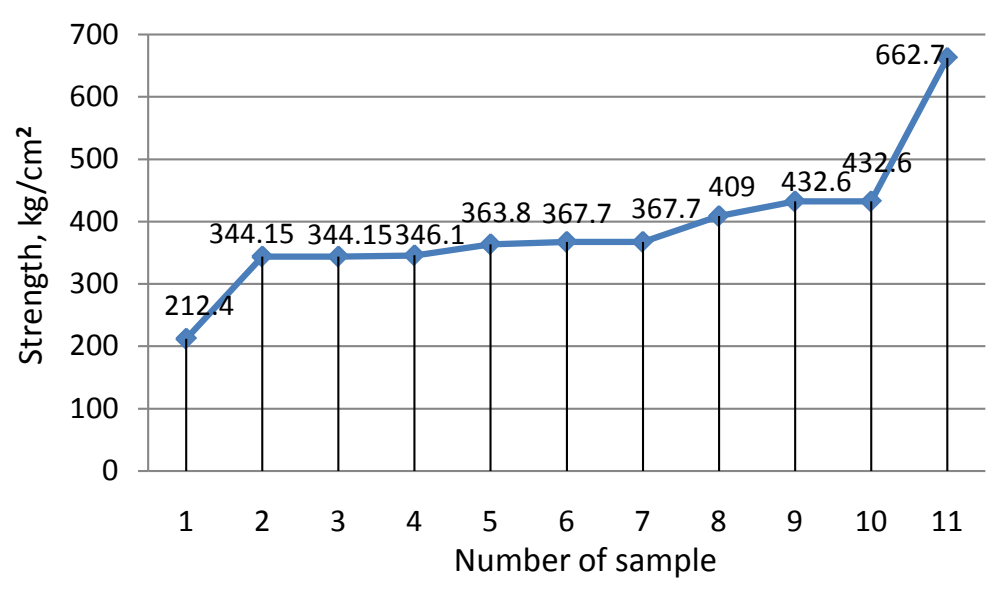

Figure 5. Changes for strength of samples.

\section{Conclusions}

As a result, the sodium liquid glass processed by kaolinite clay, with chemical composition $\left(\mathrm{g} / \mathrm{dm}^{3}\right): \mathrm{SiO}_{2}-350 ; \mathrm{Na}_{2} \mathrm{O}-155 ; \mathrm{Al}_{2} \mathrm{O}_{3}-2.1 ; \mathrm{Fe}_{2} \mathrm{O}_{3}-0.3$, silicate module-33 and density$1.49 \mathrm{~g} / \mathrm{cm}^{3}$ (complies with the Russian Interstate standard 13078-81 for sodium liquid glass) has been used for production of the modified liquid glass.

Have been synthesized 10 samples modified liquid glass from the sodium liquid glass by introducing different modifiers in an amount of $4 \%$ by weight of the solution.

It has been established that the obtained modified liquid glass from kaolinite clay can improve the strength of the quartz material for 1.6 - 3.12 times higher than the initial liquid glass. Using liquid glass modifier to the inorganic sodium nitrate $\left(\mathrm{NaNO}_{3}\right)$ increases the strength 3.12 times. Modifiers are also effective-sodium polyphosphate, sorbitol (increase the strength of 2.04 times) and sodium bromide (increase the strength 1.93 times).

\section{References}

[1] Korneev, V.I. and Danilov, V.V. (1996) Liquid and Soluble Glass. Edition of Production, Saint-Petersburg, $216 \mathrm{p}$.

[2] Kovalev, T.V., Kiseleva, L.V. and Emelyanov, O.N. (2003) A Method of Modifying Liquid Glass. A Method of Modifying Liquid Glass. Russian Patent Number 2446100.

[3] Efimenko, S.S. and Sokolov, B.A. (2013) A Method of Producing Liquid Glass from Sodium Silicat. Russian Patent Number 2495823.

[4] Boeva, N.V. Theoretical Preconditions of Effective Manufacturing for Ceramic Products Based on Modified Microsilica and Liquid Glass.

http://www.brstu.ru/images/stories/section/facultets/fmp/konf

[5] Tarasova, I.D. (2005) Low-Temperature Synthesis of Liquid Glass and Obtaining Thermal Insulating Materials Based on It. Autoabstract.

[6] Satylganova, S.B., Myltykbaeva, L.A., Sarsenbay, G., Kovzalenko, V.A. and Sadykov, N.M-K. (2012) Method for Processing of Ash from Coal. Kaz Patent Number 25939.

[7] Sarsenbay, G., Kovzalenko, V.A., Abdulvaliev, R.A., Sadykov, N.M.-K. and Imangaliev, L.M. (2016) Influence of the Concentration of Sodium Hydroxide Solution on the Leaching 
Process of Kaolinite Clay. Integrated Use of Mineral Raw Materials, 1, 28-33.

[8] Kovzalenko, V.A., Sarsenbay, G., Sadykov, N.M.-K. and Imangalieva, L.M. (2015) Kaolins-Substandard Aluminosilicate Materials. Integrated Use of Mineral Raw Materials, 3, 32-37.

[9] Russian Interstate Standard 13078-81 for Sodium Liquid Glass, USSR Decree of 27.12.91 Number 2216. Expiry Filmed.

Submit or recommend next manuscript to SCIRP and we will provide best service for you:

Accepting pre-submission inquiries through Email, Facebook, LinkedIn, Twitter, etc. A wide selection of journals (inclusive of 9 subjects, more than 200 journals)

Providing 24-hour high-quality service

User-friendly online submission system

Fair and swift peer-review system

Efficient typesetting and proofreading procedure

Display of the result of downloads and visits, as well as the number of cited articles

Maximum dissemination of your research work

Submit your manuscript at: http://papersubmission.scirp.org/

Or contact wjet@scirp.org 